\title{
The family Coriobacteriaceae: reclassification of Eubacterium exiguum (Poco et al. 1996) and Peptostreptococcus heliotrinreducens (Lanigan 1976) as Slackia exigua gen. nov., comb. nov. and Slackia heliotrinireducens gen. nov., comb. nov., and Eubacterium lentum (Prevot 1938) as Eggerthella lenta gen. nov., comb. nov.
}

\author{
William G. Wade, ${ }^{1}$ Julia Downes, ${ }^{1}$ David Dymock, ${ }^{2}$ Sarah J. Hiom, ${ }^{2}$ \\ Andrew J. Weightman, ${ }^{3}$ Floyd E. Dewhirst, ${ }^{4}$ Bruce J. Paster, ${ }^{4}$ Nia Tzellas ${ }^{4}$ \\ and Brittney Coleman ${ }^{4}$
}

\footnotetext{
1 Department of Oral Medicine and Pathology, Guy's Hospital, King's College London, London SE1 9RT, UK

2 Department of Oral and Dental Science, University of Bristol, Lower Maudlin Street, Bristol, BS1 2LY, UK

${ }^{3}$ School of Pure and Applied Biology, University of Wales, Cardiff, PO Box 915, Cardiff, CF1 3TL, UK

4 Department of Molecular Genetics, Forsyth Dental Center, Boston, MA 02115 , USA
}

\author{
Author for correspondence: William G. Wade. Tel: +44 171955 2849. Fax: +44 1719552847. \\ e-mail:w.wade@umds.ac.uk
}

\begin{abstract}
165 rRNA gene sequences were determined for Eubacterium exiguum and Peptostreptococcus heliotrinreducens. These species were found to be closely related and, together with Eubacterium lentum, to constitute a branch of the Coriobacteriaceae. Two new genera are proposed on the basis of phenotypic characteristics and 165 rRNA gene sequence comparisons: Slackia to include the bile-sensitive species Eubacterium exiguum and $P$. heliotrinreducens, and Eggerthella to include the bile-resistant Eubacterium lentum. It is proposed that Eubacterium exiguum and Peptostreptococcus heliotrinreducens are transferred to the genus Slackia gen. nov. as Slackia exigua gen. nov., comb. nov. (type strain ATCC 700122') and Slackia heliotrinireducens gen. nov., comb. nov. (type strain NTCC 11029'), respectively, and Eubacterium lentum is transferred to the genus Eggerthella gen. nov. as Eggerthella lenta gen. nov., comb. nov. with Eggerthella lenta as the type species.
\end{abstract}

Keywords: Coriobacteriaceae, Eubacterium, Peptostreptococcus, Slackia, Eggerthella

\section{INTRODUCTION}

The Gram-positive, non-sporulating, anaerobic bacilli comprising the genus Eubacterium are a heterogeneous collection of organisms. This is largely because the genus is defined by default and has become a depository for a large number of unrelated taxa (Moore $\&$ Holdeman Moore, 1986). On the basis of 16S rRNA sequence analysis, the majority of species currently classified as Eubacterium, including the type species Eubacterium limosum, belong to the low G + C Grampositive phylum (Cheeseman et al., 1996; Willems \& Collins, 1996). However, some species and unnamed

The GenBank accession numbers for the 16S rDNA of Slackia exigua and Slackia heliotrinireducens are AF101240 and AF101241, respectively. taxa provisionally identified as Eubacterium have DNA of high $\mathrm{G}+\mathrm{C}$ content (Nakazawa \& Hoshino, 1994). One such species is Eubacterium exiguum (Poco et al., 1996), formerly designated Eubacterium D6 (Moore et al., 1982, 1983), Eubacterium S-group (Sato et al., 1993) or Eubacterium Cluster 2 (Wade et al., 1990, 1994). Eubacterium exiguum is frequently found in periodontitis and periapical infections (Wade, 1997) but is difficult to identify because it is generally unreactive in conventional biochemical tests. In this, it resembles Eubacterium lentum (Moore et al., 1971), an organism found in human faeces, with which it is often confused (Wade et al., 1990). Eubacterium lentum is only rarely reported as being isolated from the mouth when tests capable of distinguishing it from Eubacterium exiguum are performed (Wade et al., 1990). 
Murdoch \& Mitchelmore (1989) described the frequent isolation from oral abscesses of strains of Peptostreptococcus heliotrinreducens, which were identified on the basis of enzyme profiles. However, the type strain of $P$. heliotrinreducens was isolated from a sheep rumen and Goodacre et al. (1996) showed by Py-MS that the isolates identified as $P$. heliotrinreducens by Murdoch \& Mitchelmore (1989) were, in fact, Eubacterium exiguum. In a phylogenetic study of the genus Peptostreptococcus based on 16S rDNA sequence comparisons, Li et al. (1994) found $P$. heliotrinreducens to be dissimilar to all other Peptostreptococcus species and, further, unlike any other prokaryotic sequence available at that time. Unfortunately, the sequence for this species was not deposited in the sequence databases and remains unavailable.

The aim of this study was to use $16 \mathrm{~S}$ rDNA sequence analysis to clarify the taxonomic positions of Eubacterium exiguum, $P$. heliotrinreducens and Eubacterium lentum.

\section{METHODS}

Bacterial strains. Eubacterium lentum NCTC $11813^{\mathrm{T}}$ and $P$. heliotrinreducens NCTC $11029^{\mathrm{T}}$ were obtained from the NCTC; Eubacterium exiguum ATCC $700122^{\mathrm{T}}$ and $P$. heliotrinreducens ATCC $29202^{\mathrm{T}}$ were obtained from the ATCC. Bacteria were maintained on Fastidious Anaerobe Agar (LabM) supplemented with 5\% horse blood and incubated under anaerobic conditions.

Biochemical tests. Fermentation tests were performed using pre-reduced, anaerobically sterilized sugars according to the methods of Holdeman et al. (1977), except that distilled water for broth preparation was pre-reduced in an anaerobic workstation. Sensitivity to bile was determined by the plate method described by Summanen et al. (1993). Other biochemical tests were performed as described by Holdeman et al. (1997).

Metabolic-end-product analysis. Bacterial strains were grown in peptone/yeast extract/glucose broth and shortchain volatile and non-volatile fatty acids extracted by standard methods (Holdeman et al., 1977). Analysis was performed by gas chromatography with a capillary column packed with a $10 \%$ free fatty acid solid phase.
Enzyme profiles. Enzyme profiles were generated with the Rapid ID32A anaerobe identification kit (bioMérieux) according to the manufacturer's instructions. Bacteria were harvested from blood agar plates [Blood Agar Base No. 2 $(\mathrm{LabM})+5 \%$ horse blood] incubated anaerobically at $37^{\circ} \mathrm{C}$ for $72 \mathrm{~h}$.

Protein profiles. Protein profiles of whole-cell proteins were generated by SDS-PAGE using $10-15 \%$ gradient gels and the PhastSystem (Pharmacia) as described previously (Slayne et al., 1990), except that the cells were pre-treated with lysozyme $\left(50 \mu \mathrm{g} \mathrm{ml}^{-1}\right)$ for $3 \mathrm{~h}$ at $37^{\circ} \mathrm{C}$.

DNA isolation and PCR amplification. DNA was released from bacteria by combining $1 \mu \mathrm{l}$ of a dense suspension of bacteria with $20 \mu$ l Gene Releaser (BioVentures) and following the manufacturer's microwave protocol. PCRs were performed in thin-walled tubes with a Perkin-Elmer 480 thermal cycler, GeneAmp7 PCR Reagent Kit and Ampliwax PCR Gem 100s. The $20 \mu \mathrm{l}$ from the Gene Releaser was combined with $1 \mu \mathrm{M}$ primers and other reagents in the Hot Start protocol suggested by PerkinElmer. Forward primer C75 (Escherichia coli numbering 7-27) 5' GAGAGTTTGATYCTGGCTCAG $3^{\prime}$ and reverse primer C90 (1501-1483) 5' GTTACGACTTCACCCTCCT $3^{\prime}$ were used. The following conditions were used for amplification: denaturation at $72{ }^{\circ} \mathrm{C}$ for $45 \mathrm{~s}$, annealing at $60^{\circ} \mathrm{C}$ for $45 \mathrm{~s}$ and elongation at $72^{\circ} \mathrm{C}$ for $45 \mathrm{~s}$, with $5 \mathrm{~s}$ added for each elongation step. A total of 30 cycles were performed, followed by a final elongation step at $72{ }^{\circ} \mathrm{C}$ for $15 \mathrm{~min}$. The purity of the product was determined by electrophoresis in a $1 \%$ agarose gel. DNA was stained with ethidium bromide and viewed under long-wavelength UV light.

Purification of PCR products. The amplified DNA was purified by precipitation with PEG 8000 (Kusukawa et al., 1990). After removal of the AmpliWax, 0.6 vols $20 \%$ PEG 8000 (Sigma) in $2.5 \mathrm{M} \mathrm{NaCl}$ were added and the mixture incubated at $37^{\circ} \mathrm{C}$ for $10 \mathrm{~min}$. The sample was centrifuged for $15 \mathrm{~min}$ at $15000 \mathrm{~g}$ and the pellet was washed with $80 \%$ ethanol and pelleted as before. The pellet was air-dried and dissolved in $30 \mu \mathrm{l}$ distilled water, and used for cycle sequencing as described below.

Sequencing methods. The DNA sample from PCR was directly sequenced using a cycle-sequencing kit ( fmol7 DNA Sequencing System; Promega), following the manufacturer's protocol. The eight sequencing primers are shown in Table 1. Primers were end-labelled with ${ }^{33} \mathbf{P}$ (NEN DuPont) using the manufacturer's protocol. Approximately $100 \mathrm{ng}$ purified

Table 1. Sequencing primers used in this study

\begin{tabular}{|llcl|}
\hline Name & \multicolumn{1}{c|}{ Sequence $\left(\mathbf{5}^{\prime} \rightarrow \mathbf{3}^{\prime}\right)$} & Position* & Orientation \\
\hline C75 & GAGAGTTTGATYCTGGCTCAG & $8-23$ & Forward \\
B34 & RCTGCTGCCTCCCGT & $344-358$ & Reverse \\
B35 & GTRTTACCGCGGCTGCTG & $519-536$ & Reverse \\
B36 & GGACTACCAGGGTATCTA & $789-806$ & Reverse \\
C01 & GGTTGCGCTCGTTGCGGG & $1096-1113$ & Reverse \\
C31 & GGAATCGCTAGTAATCG & $1337-1353$ & Forward \\
X91 & CCCGGGAACGTATTCACCG & $1369-1387$ & Reverse \\
C90 & GTTACGACTTCACCCTCCT & $1501-1483$ & Reverse \\
\hline
\end{tabular}

* Numbering based upon the sequence of $E$. coli. 
Table 2. Sources and accession numbers of strains examined

\begin{tabular}{|c|c|c|}
\hline Species & Strain or clone & $\begin{array}{c}\text { GenBank } \\
\text { accession } \\
\text { no. }\end{array}$ \\
\hline Atopobium minutum & ATCC $33267^{\mathrm{T}}$ & X67148 \\
\hline Atopobium parvulum & ATCC $33793^{\mathrm{T}}$ & $\mathrm{X} 67150$ \\
\hline Atopobium rimae & ATCC $49626^{\mathrm{T}}$ & X67149 \\
\hline Bifidobacterium breve & $\operatorname{ATCC} 15700^{\mathrm{T}}$ & M58731 \\
\hline Bifidobacterium longum & ATCC $14707^{\mathrm{T}}$ & M58739 \\
\hline Coriobacterium glomerans & ATCC $49209^{\mathrm{T}}$ & X79048 \\
\hline Eubacterium lentum & ATCC $25559^{\mathrm{T}}$ & RDP* \\
\hline Eubacterium exiguum & ATCC $700122^{\mathrm{T}}$ & AF 101240 \\
\hline Nitropropanol-degrader & NPOH1 & U43492 \\
\hline $\begin{array}{l}\text { Peptostreptococcus } \\
\text { heliotrinreducens }\end{array}$ & ATCC $29202^{\mathrm{T}}$ & AF101241 \\
\hline
\end{tabular}

* Sequence available from the Ribosomal Database Project.

DNA from the PCR was used for sequencing. Reaction products were loaded onto $8 \%$ polyacrylamide/urea gels, electrophoresed and detected by exposure to X-ray film for $24 \mathrm{~h}$.

16S rDNA data analysis. A program set for data entry, editing, sequence alignment, secondary structure comparison, similarity matrix generation and dendrogram construction for 16S rDNA data was written in Microsoft Quick BASIC for use on PC-compatible computers (Paster \& Dewhirst, 1988). Sequences were entered and aligned as previously described (Paster \& Dewhirst, 1988). Our sequence database contains approximately 1000 sequences determined in our laboratory and another 500 obtained from GenBank or the Ribosomal Database Project (Maidak et al., 1997). Reference strains used in the 16S rDNA analysis are given in Table 2. Similarity matrices were constructed from the aligned sequences by using only those sequence positions from which $90 \%$ of the strains had data. The similarity matrices were corrected for multiple base changes at single positions by the method of Jukes \& Cantor (1969). Phylogenetic trees were constructed using the neighbour-joining method of Saitou \& Nei (1987).

Estimation of $\mathbf{G}+\mathbf{C}$ content of DNA. Bacteria were grown for $7 \mathrm{~d}$ in peptone/yeast extract/glucose broth supplemented with $0.5 \%$ arginine. The cells were harvested by centrifugation and washed twice in $0.9 \% \mathrm{NaCl}, 50 \mathrm{mM}$ EDTA, $\mathrm{pH}$ 8. One gram (wet wt) of cells was then suspended in $8 \mathrm{ml}$ $0.9 \% \mathrm{NaCl}, 50 \mathrm{mM}$ EDTA, pH 8 . Lysozyme was added to $50 \mu \mathrm{g} \mathrm{ml}^{-1}$ and the suspension incubated for $30 \mathrm{~min}$ at $37^{\circ} \mathrm{C}$. Proteinase $\mathrm{K}$ was then added to $50 \mu \mathrm{g} \mathrm{ml}^{-1}$ and the suspension incubated for $1 \mathrm{~h}$ at $37^{\circ} \mathrm{C}$, followed by the addition of $1 / 10$ vol $20 \%$ SDS and incubation for $2 \mathrm{~h}$ at $37^{\circ} \mathrm{C}$. An equal volume of phenol/chloroform was added and mixed with the suspension, which was then incubated on ice for $15 \mathrm{~min}$. After centrifugation, the supernatant was removed, mixed with an equal volume of chloroform and incubated on ice for a further $15 \mathrm{~min}$. The DNA was then precipitated with 2 vols ice-cold ethanol and removed by spooling. The spooled DNA was washed in $70 \%$ ethanol and then dissolved in distilled water. RNase was added to $50 \mu \mathrm{g} \mathrm{ml}^{-1}$ and incubated for $30 \mathrm{~min}$ at $37^{\circ} \mathrm{C}$. Following a further chloroform extraction, the DNA was re-precipitated in ethanol and then dried before being dissolved in distilled water.

DNA solutions were prepared to $1 \mathrm{mg} \mathrm{ml}^{-1}$ and heated at $100^{\circ} \mathrm{C}$ for $10 \mathrm{~min}$ and then rapidly cooled in an ice bath. The denatured DNA solution $(50 \mu \mathrm{l})$ was then mixed with $50 \mu \mathrm{l}$ nuclease $\mathrm{P}_{1}$ solution ( 2 units $\mathrm{ml}^{-1}$ in $40 \mathrm{mM}$ sodium acetate buffer containing $0.2 \mathrm{mM} \mathrm{ZnCl}_{2}, \mathrm{pH} 5 \cdot 3$ ). The mixture was then incubated at $50^{\circ} \mathrm{C}$ for $1 \mathrm{~h}$ after which the hydrolysates and a standard solution containing equimolar amounts of dCMP, dAMP, dGMP and dTMP were subjected to HPLC through a LiChroCART 250-4 column (Merck). Peak heights were measured and the $\mathrm{mol} \% \mathrm{G}+\mathrm{C}$ content was calculated according to the formula of Katayama-Fujimura et al. (1984).

\section{RESULTS AND DISCUSSION}

The phylogenetic relationships between the strains included in the study are shown in Fig. 1. Eubacterium lentum, Eubacterium exiguum and $P$. heliotrinreducens fell into a cluster related to species of Atopobium within the family Coriobacteriaceae in the high-G + C Grampositive phylum. The position of the Coriobacteriaceae in this phylum is well established (Rainey et al., 1994) and was confirmed in preliminary analyses that included representatives of the high- and low-G +C Gram-positive bacteria and other phyla. The cluster also includes Coriobacterium glomerans, an endosymbiont of the red soldier bug (Haas \& König, 1988), and an unnamed nitropropanol-degrading organism (Anderson et al., 1997). The phenotypic relatedness of Eubacterium exiguum and $P$. heliotrinreducens

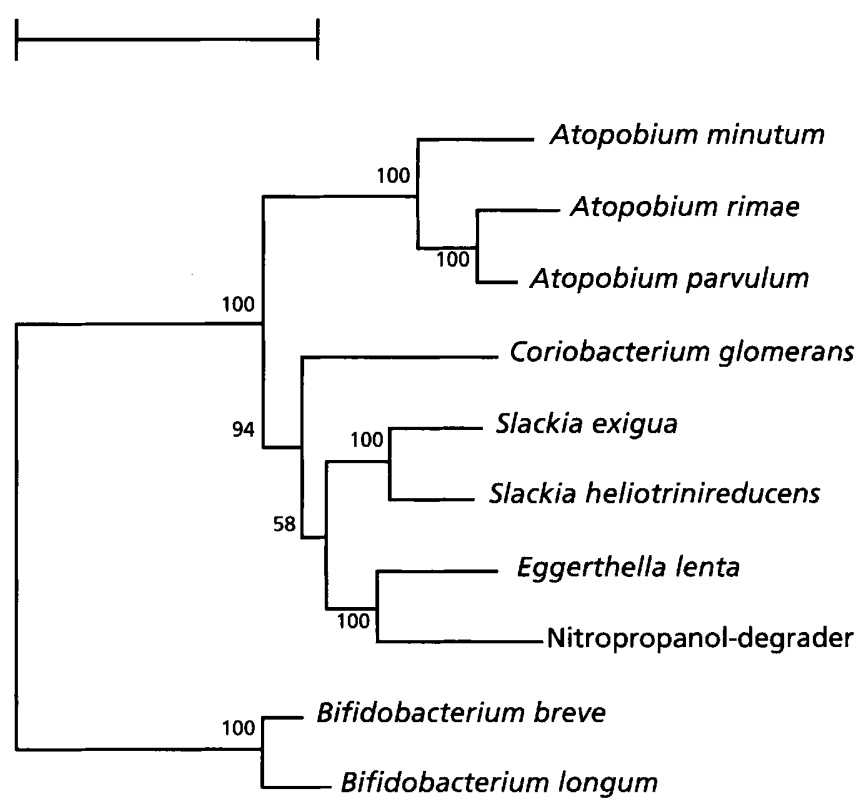

Fig. 1. $16 \mathrm{~S}$ rDNA based phylogenetic tree for the family Coriobacteriaceae. Scale bar, $10 \%$ difference in nucleotide sequences as determined by measuring the lengths of the horizontal lines connecting two sequences. The numbers are the bootstrap values for the branches based on data obtained for 1000 trees. 


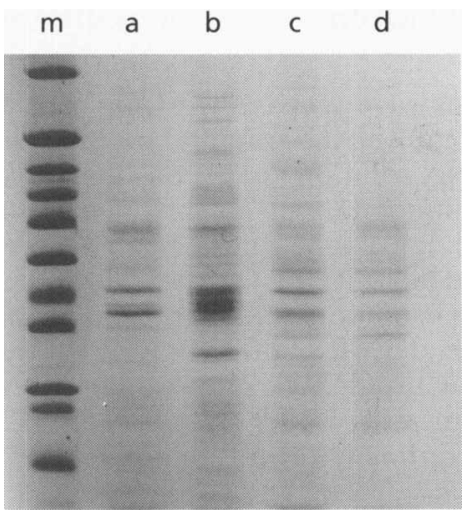

Fig. 2. Protein profiles of Eggerthella lenta, Slackia exigua and Slackia heliotrinireducens. Lane $\mathrm{m}$, molecular mass markers; lane a, Eggerthella lenta NCTC 11813 ${ }^{\mathrm{T}}$; lane b, Slackia exigua ATCC $700122^{\top}$; lane C, Slackia heliotrinireducens ATCC $29202^{\top}$; lane d, Slackia heliotrinireducens NCTC 11029'.

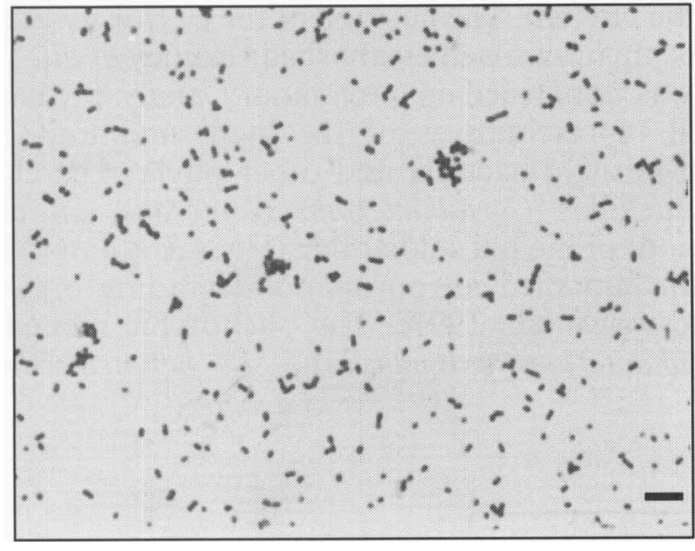

Fig. 3. Cellular morphology of Slackia heliotrinireducens (Gramstained smear, bar, $5 \mu \mathrm{m}$ ).

described previously (Goodacre et al., 1996) was confirmed by the $16 \mathrm{~S}$ rRNA sequence analysis, which showed them to be nearest neighbours in the tree; sequence similarity between the species was $94.7 \%$. Both species showed less than $91 \%$ similarity to the other strains studied.

The $\mathrm{G}+\mathrm{C}$ content of the DNA of $P$. heliotrinreducens has been reported as $36.1 \mathrm{~mol} \%$ (Lanigan, 1976) and 34-36 mol \% (Ezaki \& Yabuuchi, 1986). In this study, we estimated the $\mathrm{G}+\mathrm{C}$ content to be $61 \mathrm{~mol} \%$, which is consistent with its phylogenetic position. This degree of variation raises questions about the purity of the strain. We therefore obtained cultures from both the NCTC and ATCC and found them to be identical by enzyme and protein profiles (Fig. 2). The description of the phenotypic characters for $P$. heliotrinreducens (Lanigan, 1976) is consistent with those of the strains tested here. In addition, the cellular morphology seen in Gram-stained smears (Fig. 3) is identical to that seen in the micrograph presented by Lanigan (1976). The cells are characteristically cocci and coccobacilli found in chains, singly and in clumps. We therefore believe that the strain examined in this study is the one deposited by Lanigan (1976), but cannot explain the differences observed in $\mathrm{G}+\mathrm{C}$ values.

Eubacterium lentum and Eubacterium exiguum are both markedly distinct from Eubacterium limosum, the type species of the genus, and the other members of Eubacterium sensu stricto, which are found in the lowG + C Gram-positives (Willems \& Collins, 1996). Eubacterium lentum is found primarily in human faeces and is bile-resistant, while Eubacterium exiguum is bilesensitive and found in the mouth, mainly associated with oral infections (Poco et al., 1996). P. heliotrinreducens is also bile-sensitive and was originally isolated from the sheep rumen, which may be its only habitat. The phenotypic characteristics of Eubacterium exiguum, Eubacterium lentum and $P$. heliotrinreducens are shown in Table 3. Eubacterium exiguum and $P$. heliotrinreducens differ by only a single test in the Rapid ID 32A test panel but can be distinguished easily by their protein profiles (Fig. 2), although it appears unlikely that they would be isolated from the same specimens and therefore confused.

On the basis of 16S rRNA sequence similarity and bile sensitivity, it is proposed that Eubacterium exiguum and $P$. heliotrinreducens be placed in a new genus, Slackia, as Slackia heliotrinireducens (we have taken this opportunity to correct the epithet) and that a second new genus, Eggerthella, be created to include Eubacterium lentum, which shares only 89.8 and $90.8 \%$ 16S rRNA sequence similarity with Eubacterium exiguum and $P$. heliotrinreducens, respectively. Whether the rumen nitropropanol-degrading organism should be included in the same genus as Eubacterium lentum will have to await a more uniform phenotypic characterization of both organisms.

\section{Description of Slackia gen. nov.}

Slackia (Slack'ia. M.L. fem. n. named to honour Geoffrey Slack, distinguished British microbiologist and dental researcher).

Cells are cocci, coccobacilli or short bacilli. Grampositive, non-motile obligate anaerobes, which do not produce endospores. Bile-sensitive, hydrolyse arginine, do not produce catalase, urease or indole, and do not hydrolyse aesculin. Growth is stimulated by $0.5 \%$ arginine. Sugars are not fermented. The DNA base composition is $60-64 \mathrm{~mol} \% \mathrm{G}+\mathrm{C}$. The type species is Slackia exigua.

\section{Description of Slackia exigua (Eubacterium exiguum Poco et al. 1996) comb. nov.}

Slackia exigua (ex.i.gu'a. L. adj. exigua scanty, small, referring to the scanty or poor growth of this organism).

Characteristics of the species are as previously described by Poco et al. (1996). The type strain is ATCC 
Table 3. Characteristics of Eggerthella lenta, Slackia exigua and Slackia heliotrinireducens

\begin{tabular}{|c|c|c|c|}
\hline Test & E. lenta & S. exigua & S. heliotrinireducens \\
\hline Rapid ID 32A profile & 2000000000 & 2000033705 & 2000023705 \\
\hline Nitrate reduction & + & - & + \\
\hline Bile growth & 4 & - & - \\
\hline $\begin{array}{l}\text { Fermentation products } \\
\text { from glucose* }\end{array}$ & $\begin{array}{l}\text { (Acetate), (lactate), } \\
\text { (succinate) }\end{array}$ & None detected & Acetate \\
\hline $\mathrm{G}+\mathrm{C}$ content $(\mathrm{mol} \%)$ & 62 & $60-64$ & $61 \dagger$ \\
\hline \multicolumn{4}{|l|}{ Morphology: } \\
\hline Shape & Rods & $\begin{array}{l}\text { Rods; single, } \\
\text { clumps }\end{array}$ & $\begin{array}{l}\text { Cocci and coccobacilli in } \\
\text { chains and clumps }\end{array}$ \\
\hline Size $(\mu \mathrm{m})$ & $0 \cdot 2-0 \cdot 4 \times 0 \cdot 2-2 \cdot 0$ & $0.5 \times 1.0$ & $0.8 \times 0.8-1.2$ \\
\hline
\end{tabular}

* Fermentation products in parentheses indicates strain variation.

$\dagger$ Type strain, this study.

$700122^{\mathrm{T}}$. The $16 \mathrm{~S}$ rRNA gene sequence for the type strain has been deposited in GenBank under accession number AF101240.

\section{Description of Slackia heliotrinireducens (Peptostreptococcus heliotrinreducens Lanigan 1976) comb. nov.}

Slackia heliotrinireducens (he.li.o.trin.i.re.duc.ens. M.L. n. heliotrinum derived from heliotrine, a pyrrolizidine alkaloid; L. adj. reducans reducing M.L. adj. heliotrinireducens referring to the organisms ability to bring about oxidative cleavage of the heliotrine molecule).

Characteristics of the species are as previously described for Peptostreptococcus heliotrinreducens (Lanigan, 1976). The type strain is NCTC $11029^{\mathrm{T}}$. The $16 \mathrm{~S}$ rDNA sequence for the type strain has been deposited in GenBank under accession number AF101241.

\section{Description of Eggerthella gen. nov.}

Eggerthella [Egg.er.thel'la. M.L. fem. n. named to honour Arnold Eggerth, who first described the organism later named Eubacterium lentum (Eggerth 1935)].

Characteristics of the genus are as previously described for Eubacterium lentum (Moore et al., 1971). The type species is Eggerthella lenta.

\section{Description of Eggerthella lenta (Eubacterium lentum Prevot 1938) comb. nov.}

Eggerthella lenta (len'tum. L. neut. adj. lentum slow).

Characteristics of the species are as previously described by Moore et al. (1971). The type strain is NCTC $11813^{\mathrm{T}}$.

\section{ACKNOWLEDGEMENTS}

Dr F. Nakazawa is thanked for assistance with the HPLC analysis. This work was supported in part by USA Public Health Service grants DE-10374 (F.E.D.) and DE-11443 (B.J.P.) from the National Institute of Dental Research.

\section{REFERENCES}

Anderson, R. C., Rasmussen, M. A., DiSpirito, A. A. \& Allison, M. J. (1997). Characteristics of a nitropropanol-metabolising bacterium isolated from the rumen. Can $J$ Microbiol 43, 617-624.

Cheeseman, S. L, Hiom, S. J., Weightman, A. J. \& Wade, W. G. (1996). Phylogeny of oral asaccharolytic Eubacterium species determined by $16 \mathrm{~S}$ ribosomal DNA sequence comparison and proposal of Eubacterium infirmum sp.nov. and Eubacterium tardum sp. nov. Int $J$ Syst Bacteriol 46, 957-959.

Eggerth, A. (1935). The gram-positive non-spore-bearing anaerobic bacilli of human faeces. $J$ Bacteriol 30, 277--299.

Ezaki, T. \& Yabuuchi, E. (1986). Transfer of Peptococcus heliotrinreducens corrig. to the genus Peptostreptococcus: Peptostreptococcus heliotrinreducens Lanigan 1983 comb. nov. Int $J$ Syst Bacteriol 36, 107-108.

Goodacre, R., Hiom, S. J., Cheeseman, S. L., Murdoch, D., Weightman, A. J. \& Wade, W. G. (1996). Identification and discrimination of oral asaccharolytic Eubacterium spp. by pyrolysis mass spectrometry and artificial neural networks. Curr Microbiol 32, 77-84.

Haas, F. \& König, H. (1988). Coriobacterium glomerans gen nov., sp. nov. from the intestinal tract of the red soldier bug. Int J Syst Bacteriol 38, 382-384.

Holdeman, L. V. H., Cato, E. P. \& Moore, W. E. C. (1977). Anaerobe Laboratory Manual, 4th edn. Blacksburg: Virginia Polytechnic and State University.

Jukes, T. H. \& Cantor, C. R. . (1969). Evolution of protein molecules. In Mammalian Protein Metabolism, pp. 21-132. Edited by H. N. Munro. New York: Academic Press.

Katayama-Fujimura, Y., Komatsu, Y., Kuraishi, H. \& Kaneko, T. (1984). Estimation of DNA base composition by high performance liquid chromatography of its nuclease $\mathrm{P} 1$ hydrolysate. Agric Biol Chem 48, 3169-3172. 
Kusukawa, N., Uemori, T., Asada, K. \& Kato, I. (1990). Rapid and reliable protocol for direct sequencing of material amplified by the polymerase chain reaction. Biotechniques 9, 66-68.

Lanigan, G. W. (1976). Peptococcus heliotrinreducans, sp.nov., a cytochrome-producing anaerobe which metabolises pyrrolizidine alkaloids. $J$ Gen Microbiol 94, 1-10.

Li, N., Hashimoto, Y. \& Ezaki, T. (1994). Determination of $16 \mathrm{~S}$ ribosomal RNA sequences of all members of the genus Peptostreptococcus and their phylogenetic position. FEMS Microbiol Lett 116, 1-6.

Maidak, B. L., Olsen, G. J., Larsen, N., Overbeek, R., McCaughey, M. J. \& Woese, C. R. (1997). The RDP (Ribosomal Database Project). Nucleic Acids Res 25, 109-111.

Moore, W. E. C. \& Holdeman Moore, L. V. (1986). Genus Eubacterium Prévot $1938294^{\mathrm{AL}}$. In Bergey's Manual of Systematic Bacteriology, vol 2, pp. 1353-1373. Edited by P. H. A. Sneath. Baltimore: Williams \& Wilkins.

Moore, W. E. C, Cato, E. P. \& Holdeman, L. V. (1971). Eubacterium lentum (Eggerth) Prevot 1938: emendation of description and designation of the neotype strain. Int $J$ Syst Bacteriol 21, 299-303.

Moore, W. E. C, Holdeman, L. V., Smibert, R. M., Hash, D. E., Burmeister, J. A. \& Ranney, R. R. (1982). Bacteriology of severe periodontitis in young adult humans. Infect Immun 38, $1137-1148$.

Moore, W. E. C, Holdeman, L. V., Cato, E. P., Smibert, R. M., Burmeister, J. A. \& Ranney, R. R. (1983). Bacteriology of moderate (chronic) periodontitis in mature adult humans. Infect Immun 39, 510-515.

Murdoch, D. A. \& Mitchelmore, I. J. (1989). Isolation of Peptostreptococcus heliotrinreducens from human polymicrobial abscesses. Lett Appl Microbiol 19, 223-225.

Nakazawa, F. \& Hoshino, E. (1994). Genetic relationships among Eubacterium species. Int J Syst Bacteriol 44, 787-790.

Paster, B. J. \& Dewhirst, F. E. (1988). Phylogeny of campylobacters, wolinellas, Bacteroides gracilis and Bacteroides ureolyticus by $16 \mathrm{~S}$ ribosomal ribonucleic acid sequencing. Int $J$ Syst Bacteriol 38, 56-62.

Poco, S. E., Jr, Nakazawa, F., Ikeda, T., Sato, M., Sato, T. \& Hoshino, E. (1996). Eubacterium exiguum sp. nov., isolated from human oral lesions. Int $J$ Syst Bacteriol 46, 1120-1124.

Rainey, F. A., Weiss, N. \& Stackebrandt, E. (1994). Coriobacterium and Atopobium are phylogenetic neighbours within the actinomycetes line of descent. Syst Appl Microbiol 17, 202-205.

Saito, N. \& Nei, M. (1987). The neighbor-joining method: a new method for constructing phylogenetic trees. Mol Biol Evol 4, 406-425.

Sato, T., Hoshino, E., Uematsu, H. \& Noda, T. (1993). Predominant obligate anaerobes in necrotic pulps of human deciduous teeth. Microb Ecol Health Dis 6, 269-275.

Slayne, M. A., Aldred, M. J. \& Wade, W. G. (1990). A rapid, semiautomated SDS-PAGE identification system for oral anaerobic bacteria. J Appl Bacteriol 68, 385-390.

Summanen, P., Baron, E. J., Citron, D. M., Strong, C. A., Wexler, H. M. \& Finegold, S. M. (1993). Wadsworth Anaerobic Bacteriology Manual, 5th edn. Belmont, CA: Star Publishing.

Wade, W. G. (1997). The role of Eubacterium species in periodontal disease and other oral infections. Microb Ecol Health Dis 9, 367-370.

Wade, W. G., Slayne, M. A. \& Aldred, M. J. (1990). Comparison of identification methods for oral asaccharolytic Eubacterium species. J Med Microbiol 33, 239-242.

Wade, W. G., Lewis, M. A. O., Cheeseman, S. L., Absi, E. G. \& Bishop, P. A. (1994). An unclassified Eubacterium taxon in acute dentoalveolar abscess. $J$ Med Microbiol 40, 115-117.

Willems, A. \& Collins, M. D. (1996). Phylogenetic relationships of the genera Acetobacterium and Eubacterium sensu stricto and reclassification of Eubacterium alactolyticum as Pseudoramibacter alactolyticus gen. nov., comb. nov. Int J Syst Bacteriol 46, 1083-1087. 